\title{
Kejadian Preeklampsia dan Faktor Risiko yang Mempengaruhinya
}

\section{Preeclampsia Incidence and Its Related Risk Factors}

\author{
Safrudin Tolinggi ${ }^{1 *}$, Kasma Mantulangi'2) dan Nuryani1) \\ ${ }^{1}$ Ilmu Gizi, Fakultas Kesehatan Masyarakat, Universitas Gorontalo \\ *email: safrudin.tolinggi@gmail.com \\ ${ }^{1}$ Ilmu Kesehatan Masyarakat, Fakultas Kesehatan Masyarakat, Universitas Gorontalo
}

\begin{abstract}
One cause of maternal morbidity and mortality is preeclampsia. The purpose of this research was to determine the risk factors of preeclampsia. The type of research was observational analytic using a case control study to determine risk factors for the incidence of preeclampsia in pregnant women. The population in this study as many as 1182 people and the sample size of 168 people consisting of case and control samples. Sampling technique was used purposive sampling. Results was showed that analysis unvariate parity 1 and $>3$ as many as $62,5 \%$, the distance of pregnancy $<2$ years and $>5$ years as many as $35,7 \%$ and education $<9$ years as many as $33,3 \%$. Analysis bivariate with odds ratio values obtained $\mathrm{OR}=1.052$, with a lower limit value $(0.563)$ and the upper limit $(1.965)$ then parity was significant risk factor on the incidence of preeclampsia. Results of statistical bivariate analysis $\mathrm{OR}=2.088$, with a lower limit value (1.096) and the upper limit (3.978) then the distance pregnancy was significant risk factor on the incidence of preeclampsia. Results of statistical bivariate analysis odds ratio values obtained $\mathrm{OR}=1.239$, with a lower limit value $(0.652)$ and the upper limit (2.354) then education was a significant risk factor on the incidence of preeclampsia. The conclusion of this study was the parity, gap of pregnancy and education were the risk factor for preeclampsia in pregnant women.
\end{abstract}

Keywords; age, education, gap of pregnancy, parity, preeclampsia

\section{Abstrak}

Salah satu penyebab morbiditas dan mortalitas ibu adalah preeclampsia. Tujuan dalam penelitian ini adalah untuk mengetahui faktor risiko kejadian preeclampsia. Jenis penelitian yang digunakan adalah observasional analitik dengan menggunakan rancangan case control study untuk mengetahui faktor risiko kejadian preeklampsia pada ibu hamil. Populasi dalam penelitian ini sebanyak 1182 orang dan jumlah sampel 168 orang yang terdiri dari sampel kasus dan kontrol. Tehnik pengambilan sampel secara purposive sampling. Hasil penelitian menunjukkan analisis univariat paritas 1 dan $>3$ sebanyak $62,5 \%$, jarak kehamilan $<2$ tahun dan $>5$ tahun sebanyak 35,7\% dan pendidikan $<9$ tahun sebanyak $33,3 \%$. Analisis bivariat dengan uji odds ratio diperoleh nilai $\mathrm{OR}=1,052$, dengan nilai lower limit $(0,563)$ dan upper limit $(1,965)$ maka paritas merupakan faktor risiko yang bermakna terhadap kejadian preeklampsia. Hasil analisis statistik bivariat dengan uji odds ratio dengan nilai $\mathrm{OR}=2,088$, dengan nilai lower limit $(1,096)$ dan upper limit $(3,978)$ maka jarak kehamilan merupakan faktor risiko yang bermakna terhadap kejadian preeklampsia. Hasil analisis statistik bivariat dengan uji odds ratio diperoleh nilai $\mathrm{OR}=1,239$, dengan nilai lower limit $(0,652)$ dan upper limit $(2,354)$ maka pendidikan merupakan faktor risiko yang bermakna terhadap kejadian preeklampsia. Kesimpulan dari 
penelitian ini adalah paritas, jarak kehamilan dan pendidikan merupakan faktor risiko kejadian preeklampsia pada ibu hamil.

Kata kunci; umur, jarak kehamilan, pendidikan, paritas, preeklmpsia

\section{PENDAHULUAN}

Preeklampsia adalah komplikasi kehamilan dan merupakan salah satu penyebab utama dari kesakitan dan kematian ibu hamil di Indonesia. Preeklampsia ditandai dengan peningkatan tekanan darah (hipertensi), ditemukannya protein dan albumin dalam urine dan edema. Preeklampsia dapat terjadi pada sekitar 3\% sampai 5\% (Senden, 2011). Karaketristik ibu turut berperan terhadap kejadian preeklampsia. Karakterisik tersebut dapat meliputi usia, paritas, jarak kehamilan dan pendidikan. Penelitian di kota Palu mendapatkan bahwa pendidikan, sosial ekonomi, riwayat preeklampsia/eklampsia, umur, paritas dan penyakit diabetes merupakan faktor risiko terhadap kejadian preeklampsia (Kusika dkk, 2014). Umur > 35 tahun ( $p$ value 0,040$)$, paritas 2-3 ( $p$ value 0,040 ) dan jarak kehamilan $>5$ tahun $(60,6 \% ; p$ value 0,028$)$ berhubungan dengan kejadian preeklampsia (Hadjiko, 2014). Usia kurang dari 20 tahun atau lebih dari 35 tahun berhubungan dengan preeklampsia (Ika, 2009). Umur ibu hamil $<20$ tahun atau $>35$ tahun berisiko 3,144 kali dan primigravida berisiko 2,147 kali mengalami preeklampsia (Asrianti, 2009).

Karakteristik demografi penduduk diduga berhubungan dengan kejadian preeklampsia pada ibu hamil. Berdasarkan penelitian yang dilakukan oleh Kiondo et al. (2012) di Rumah Sakit Mulago, Kampala Uganda menemukan bahwa ibu dengan pendidikan rendah berisiko 1,67 kali mengalami kejadian preeklampsia pada kehamilan. Hasil penelitian di Manado mendapatkan bahwa kejadian preeklampsia banyak ditemukan pada tingkat pendidikan SMA yakni preekalmsia ringan (PER) 68,36\% dan preeclampsia berat (PEB) 76,7\%, multigravida PER 62\% dan PEB 59\%, jarak persalinan 2-5 tahun PER 51,02\% dan PEB 52\% (Hutabarat dkk, 2016).

World Health Organization (WHO) melaporkan bahwa prevalensi wanita hamil yang mengalami hipertensi sekitar $35-55 \%$ serta semakin meningkat seiring dengan bertambahnya usia kehamilan. WHO menyatakan pula bahwa $20 \%$ kematian ibu di negara berkembang berkaitan dengan hipertensi pada kehamilan. Hasil riset kesehatan dasar tahun 2007 menunjukkan bahwa 24,5\% wanita subur menderita hipertensi pada saat kehamilan (Kemenkes, 2008). Data yang diperoleh di Rumah Sakit Toto Kabila Kabupaten Bone Bolango yang tercatat dalam rekam medik tahun 2013 dari kunjungan ibu hamil sebanyak 1030, yang didiagnosa menderita preeklampsia berjumlah $104 \quad(10,1 \%)$ dan pada tahun 2014 dari kunjungan ibu hamil sebanyak 1182, yang didiagnosa menderita preeklampsia berjumlah 183 (15,48 \%). Penelitian ini bertujuan untuk menilai risiko kejadian preeklampsia pada ibu hamil di RSU Daerah Toto Kabila Kabupaten Bone Bolango.

\section{METODE}

Jenis penelitian yang digunakan adalah penelitian observasional analitik dengan menggunakan pendekatan retrospektif atau studi kasus kontrol (case control study) dengan perhitungan odds ratio (OR). Lokasi penelitian di RSU Daerah Toto Kabila Kabupaten Bone Bolango dan dilakukan pada Mei-Juni tahun 2015. Populasi dalam penelitian ini adalah seluruh ibu hamil yang menderita preeklampsia dan yang tidak menderita preeklampsia dan tercatat di RSU Daerah Toto Kabila Bone Bolango tahun 2014 sebanyak 1182 ibu hamil. 
Adapun sampel dalam penelitian ini adalah dengan menggunakan kasus dan kontrol dengan perbandingan 1:1. Kasus adalah seluruh ibu hamil yang didiagnosa preeklampsia berjumlah 84 ibu hamil dan kontrol adalah seluruh ibu hamil yang bukan preeklampsia dan tercatat di buku register kebidanaan sebanyak 84 ibu hamil, jumlah sampel dalam penelitian ini sebanyak 168 . Tekhnik pengambilan sampel yang digunakan adalah menggunakan purposive sampling. Pengumpulan data menggunakan data sekunder yang diperoleh dari medical record. Pengolahan data dilakukan secara menual dan eletronik dengan menggunakan kalkulator dan komputer. Analisis data secara univariat dan bivariat untuk melihat hubungan antara variabel. Analisis bivariat variabel penelitian dikelompokkan menjadi kategori risiko tinggi dan risiko rendah. Variabel paritas dikatakan berisiko tinggi jika paritas 1 atau di atas 3 . Variabel jarak kehamilan dikategorikan berisiko tinggi jika dibawah 2 tahun atau diatas sama dengan 5 tahun. Kategori pendidikan dikategorikan berisiko jika di bawah SLTP atau sederajat.

\section{HASIL DAN PEMBAHASAN}

\section{Analisis Univariat Karakteristik Subjek Penelitian}

Karakteristik umur dan pendidikan subjek penelitian ditunjukkan pada Tabel 1. Tabel 1 menunjukkan bahwa dari 168 responden, berdasarkan umur distribusi tertinggi pada umur 20-25 tahun yaitu sebanyak 47 responden $(28,0 \%)$ dan yang terendah pada umur $>44$ tahun yaitu sebnyak sebanyak 2 responden $(1,2 \%)$. Berdasarkan pendidikan distribusi tertinggi pada responden yang mempunyai pendidikan SMA yaitu sebanyak $60(35,7 \%)$ dan yang terendah ada pada responden yang mempunyai pendidikan S2 yaitu sebanyak $1(0,6 \%)$.

\begin{tabular}{|c|c|c|}
\hline \multirow{2}{*}{ Karaktersitik } & \multicolumn{2}{|c|}{ Total } \\
\hline & & \\
\hline \multicolumn{3}{|l|}{ Umur } \\
\hline 14-19 & 23 & 13,7 \\
\hline $20-25$ & 47 & 28,0 \\
\hline $26-31$ & 36 & 21,4 \\
\hline $32-37$ & 40 & 23,8 \\
\hline $38-43$ & 20 & 11,9 \\
\hline$>44$ & 2 & 1,2 \\
\hline \multicolumn{3}{|l|}{ Pendidikan } \\
\hline $\mathrm{SD}$ & 56 & 33,3 \\
\hline SMP & 31 & 18,5 \\
\hline SMA & 60 & 35,7 \\
\hline DIPLOMA & 9 & 5,4 \\
\hline $\mathrm{S} 1$ & 11 & 6,5 \\
\hline $\mathrm{S} 2$ & 1 & 0,6 \\
\hline Jumlah & 168 & 100 \\
\hline
\end{tabular}

Distribusi subjek penelitian berdasarkan status paritas, jarak kehamilan dan pendidikan ditunjukkan pada Tabel 2. Dari 168 responden, berdasarkan paritas distribusi tertinggi adalah yang beresiko tinggi ( 1 dan $>3$ ) yaitu sebanyak 105 responden $(62,5 \%)$ dan yang terendah adalah yang beresiko rendah (2 dan 3 ) yaitu sebanyak 63 responden (37,5\%). Berdasarkan jarak kehamilan distribusi tertinggi adalah yang beresiko rendah yaitu sebanyak 108 responden (64,3\%) dan yang terendah adalah yang beresiko tinggi yaitu sebanyak 60 responden 
$(35,7 \%)$. Berdasarkan jarak kehamilan distribusi tertinggi adalah yang beresiko rendah yaitu sebanyak 112 responden (66,7\%) dan yang terendah adalah yang beresiko tinggi yaitu sebanyak 56 responden $(33,3 \%)$.

Tabel 2. Distribusi responden berdasarkan variabel penelitian pada ibu hamil di RSU Daerah Toto Kabila Kabupaten Bone Bolango

\begin{tabular}{|c|c|c|}
\hline \multirow{2}{*}{ Variabel penelitian } & \multicolumn{2}{|c|}{ Total } \\
\hline & $\mathrm{n}$ & $\%$ \\
\hline \multicolumn{3}{|l|}{ Paritas } \\
\hline 1 dan $>3$ & 105 & 62,5 \\
\hline 2 dan 3 & 63 & 37,5 \\
\hline \multicolumn{3}{|l|}{ Jarak kehamilan } \\
\hline$<2$ dan $>5$ tahun & 60 & 35,7 \\
\hline 2 dan 5 tahun & 108 & 64,3 \\
\hline \multicolumn{3}{|l|}{ Pendidikan } \\
\hline$<$ SLTP & 56 & 33,3 \\
\hline$\geq$ SLTP & 112 & 66,7 \\
\hline Jumlah & 168 & 100 \\
\hline
\end{tabular}

Hasil analisis univariat menunjukkan kelompok paritas 1 dan $>3$ sebanyak $62,5 \%$, jarak kehamilan $2-5$ tahun sebanyak 64,3\% dan tingkat pendidikan di atas 9 tahun 66,7\%. Pada variabel paritas lebih banyak dalam kelompok yang berisiko yakni paritas 1 dan $>3$ hasil penelitian ini hampir sama dengan hasil penelitian Nuryani dkk (2013) di Makassar yang menyatakan bahwa kelompok preeclampsia lebih tinggi pada paritas berisiko yakni 80,0\%. Variabel jarak kehamilan lebih tinggi pada jarak kehamilan tidak berisiko yakni $2-5$ tahun, berebeda dengan penelitian sebelumnya yang mendapatkan bahwa kelompok jarak kelamilan berisiko yakni $<2$ tahun atau $>5$ tahun lebih banyak pada kelompok preeclampsia yakni 52,9\%. Variabel tingkat pendidikan lebih banyak pada tingkat pendidikan $\geq$ SLTP, hal ini hampir sama dengan temuan penelitian sebelumnya yang menyatakan bahwa subjek penelitian dengan tingkat pendidikan cukup 68,3\% (Nuryani, dkk, 2013).

\section{Analisis Faktor Risiko Kejadian Preeklampsia}

Analisis faktor risiko kejadian preeklampsia yang dimasukkan dalam penelitian ini ditunjukkan pada Tabel 3. Berdasarkan variabel paritas sebanyak 53 responden $(63,1 \%)$ berisiko tinggi dan sebanyak 31 responden $(36,9 \%)$ yang beresiko rendah, sedangkan jumlah kontrol yang beresiko tinggi adalah 52 responden $(61,9 \%)$, dan yang beresiko rendah 32 responden $(38,1 \%)$. Analisis odds ratio diperoleh nilai $\mathrm{OR}=1,052(95 \% \mathrm{CI}: 0,563-1,965)$ maka dikatakan paritas beresiko 1,052 kali untuk mengalami preeklampsia. Distribusi kasus yang beresiko tinggi menurut variable jarak kehamilan sebesar 37 responden $(44,0) \%$ dan yang beresiko rendah adalah 47 responden $(56,0 \%)$, sedangkan jumlah kontrol yang beresiko tinggi adalah 23 responden $(27,4 \%)$, dan yang beresiko rendah 61 responden $(72,6 \%)$. Analisis odds ratio diperoleh nilai OR = 2,088 (95\% CI: 1,096 - 3,978) sehingga jarak kehamilan beresiko 2,088 kali untuk mengalami pre-eklampsia. Distribusi kasus yang beresiko tinggi menurut variable pendidikan 30 responden $(35,7 \%)$ dan yang beresiko rendah adalah 54 responden $(64,3 \%)$, sedangkan jumlah kontrol yang beresiko tinggi adalah 26 responden $(31,0 \%)$, dan yang beresiko rendah 58 responden $(69,0 \%)$. Hasil analisis odds ratio diperoleh OR $=1,239$ (95\% CI: 0,652 - 2,354), sehingga pendidikan rendah beresiko 1,239 kali untuk mengalami pre-eklampsia. 
Tabel 3. Analisis risiko kejadian preeklampsia pada ibu hamil di RSU Daerah Toto Kabila Kabupaten Bone Bolango

\begin{tabular}{|c|c|c|c|c|c|c|c|}
\hline \multirow{3}{*}{$\begin{array}{l}\text { Variabel } \\
\text { penelitian }\end{array}$} & \multicolumn{4}{|c|}{ Status Preeklampsia } & \multirow{3}{*}{$\mathrm{N}$} & \multirow{3}{*}{$\%$} & \multirow{3}{*}{$\begin{array}{c}\text { OR } \\
\text { CI }=95 \%\end{array}$} \\
\hline & \multicolumn{2}{|c|}{ Kasus } & \multicolumn{2}{|c|}{ Kontrol } & & & \\
\hline & $\mathrm{n}$ & $\%$ & $\mathrm{n}$ & $\%$ & & & \\
\hline Paritas & & & & & & & $\mathrm{OR}=1,052$ \\
\hline Risiko Tinggi & 53 & 63,1 & 52 & 61,9 & 105 & 62,5 & $\mathrm{LL}=0,563$ \\
\hline Risiko Rendah & 31 & 36,9 & 32 & 38,1 & 63 & 37,5 & $\mathrm{UL}=1,965$ \\
\hline Jarak kehamilan & & & & & & & $\mathrm{OR}=2,088$ \\
\hline Risiko Tinggi & 37 & 44,0 & 23 & 27,4 & 60 & 35,7 & $\mathrm{LL}=1,096$ \\
\hline Risiko Rendah & 47 & 56,0 & 61 & 72,6 & 108 & 64,3 & $\mathrm{UL}=3,978$ \\
\hline Pendidikan & & & & & & & \\
\hline Risiko tinggi & 30 & 35,7 & 26 & 31,0 & 56 & 33,3 & $\begin{array}{l}O R=1,239 \\
L L=0652\end{array}$ \\
\hline Risiko Rendah & 54 & 64,3 & 58 & 69,0 & 112 & 66,7 & $\begin{array}{l}\mathrm{LL}=0,652 \\
\mathrm{UL}=2,354\end{array}$ \\
\hline Jumlah & 84 & 100 & 84 & 100 & 168 & 100 & \\
\hline
\end{tabular}

Paritas 1 atau lebih dari 3 berisiko 1,052 kali terhadap kejadian preeklampsia. Hasil penelitian ini sejalan dengan penelitian Hadjiko (2014) yang mendapatkan bahwa paritas $2-3(45,5 \%$; $p$ value 0,040$)$, dan juga sejalan dengan hasil penelitian yang dilakukan oleh Rahmadani dkk (2013) yang menyatakan bahwa paritas merupakan hubungan yang bermakna terhadap kejadian preeklampsia pada ibu hamil. Namun, hasil penelitian ini tidak sesuai dengan hasil penelitian Nuryani dkk (2013) di kota Makassar mendapatkan bahwa tingkat pendidikan, umur dan paritas tidak berhubungan dengan kejadian preeklampsia. Preeklampsia dapat dijumpai pada paritas (anak pertama), hal ini disebabkan karena kehamilan dengan preeklampsia lebih umum terjadi pada paritas (anak pertama), hal ini tidak berbeda dengan teori yang mengatakan bahwa salah satu predisposisi terjadinya preeklampsia berat adalah faktor paritas (anak pertama), Keadaan ini disebabkan pada kehamilan pertama pembentukan antibodi penghambat belum sempurna sehingga ibu belum siap secara medis dan secara mental biasanya ibu sering merasa cemas dalam proses persalinan sehingga cenderung untuk mengalami stres saat kehamilan. Sementara, paritas $>3$ kehamilan/kelahiran lebih banyak yang menderita preeklampsia karena persalinan yang berulang akan menyebabkan di dalam tubuh seorang ibu terjadi perubahan akibat kerusakan organ-organ yang dapat menyebabkan ibu mengalami gangguan dalam masa kehamilan, sehingga mempunyai banyak risiko terhadap kehamilan seperti terjadinya preeklampsia, selain itu mereka juga mempunyai penyakit vascular termasuk hipertensi essensial yang kronik dan diabetes mellitus, sehingga persalinan kedua dan ketiga adalah persalinan yang paling aman.

Jarak kehamilan kurang dari 2 tahun atau di atas 5 tahun berisiko 2,088 terhadap kejadian preeklampsi. Hasil penelitian ini sejalan dengan hasil penelitian Hadjiko (2014) di RSUD Prof. Dr. H. Aloei saboe Kota Gorontalo pada 33 subjek penelitian menunjukkan bahwa sebagian besar responden yang mengalami preeklampsia adalah umur $>35$ tahun $(42,4 \% ; p$ value 0,040$)$ dan jarak kehamilan $>5$ tahun $(60,6 \% ; p$ value 0.028$)$, penelitian tersebut menyimpulkan bahwa terdapat hubungan karakteristik ibu hamil berdarakan umur, paritas, dan jarak kehamilan dengan kejadian preeklampsia. Hal ini hampir sama dengan hasil penelitian yang dilakukan oleh Betty dkk (2009) yang menemukan bahwa jarak kelahiran berhubungan dengan kejadian preeklampsia adalah $\geq 5$ tahun. Hasil penelitian ini sesuai dengan hasil penelitian Nuryani dkk (2013) di Makassar yang mendapatkan bahwa tidak ada hubungan antara jarak kehamilan dengan kejadian preeklampsia. Menurut Rozikhan (2007) jarak 
antar kehamilan yang terlalu dekat (kurang dari 2 tahun) dapat meningkatkan risiko untuk terjadinya kematian maternal, jarak antar kehamilan yang disarankan pada umumnya adalah paling sedikit dua tahun. Jarak kehamilan < 2 tahun semakin besar beresiko terhadap kejadian preeklampsia, karena jarak kehamilan yang terlalu dekat secara fisik, kondisi ini ibu belum pulih secara total, dan pemenuhan zat-zat gizi belum optimal untuk menghadapi proses persalinan. Sebagian besar responden dengan jarak kelahiran beresiko rendah lebih banyak mengalami preeklampsia.

Tingkat pendidikan tidak tamat SLTP atau sederajat memberikan risiko 1,239 terhadap kejadian preeklampsia. Hasil penelitian Kusika dkk (2014) di kota Palu mendapatkan bahwa pendidikan, sosial ekonomi, riwayat preeklampsia/eklampsia, umur, paritas dan penyakit diabetes merupakan faktor risiko terhadap kejadian preeklampsia. Pemanfaatan pelayanan ANC merupakan faktor proteksi terhadap kejadian preeklampsia. Hasil penelitian Ika (2009) didapatkan bahwa faktor yang menyebabkan meningkatnya insiden preeklampsia pada ibu hamil antara lain molahidatidosa, nulipara, usia kurang dari 20 tahun atau lebih dari 35 tahun, janin lebih dari satu, multipara, hipertensi kronis, diabetes mellitus atau penyakit ginjal. Namun hasil penelitian ini tidak didukung oleh hasil penelitian yang dilakukan oleh Rozikhan (2007) yang menunjukkan tidak ada perbedaan pada status pendidikan ibu hamil untuk menyebabkan preeklampsia berat. Tingkat pendidikan turut menentukan mudah tidaknya seseorang memahami pengetahuan tentang penyakit preeklampsia. Kurangnya pengetahuan dan persepsi tentang kesehatan terutama kesehatan reproduksi mengakibatkan terbatasnya pemahaman dan akses ibu terhadap pelayanan kesehatan.

\section{PENUTUP}

Berdasarkan pada hasil penelitian disimpulkan bahwa besar risiko paritas terhadap kejadian preeklampsia 1,052 kali, bersar risiko jarak kehamilan adalah 2,088 kali dan pendidikan 1,239 kali menderita pre-eklampsia.Disarankan kepada pihak rumah sakit hendaknya memberikan pengawasan antenatal, deteksi dini dan penanganan yang baik dalam mengatasi ibu hamil dan bersalin yang beresiko sehingga dapat mencegah terjadinya preeklampsia berat dan dapat menurunkan angka kematian ibu.

\section{DAFTAR PUSTAKA}

Asrianti T. 2009. Faktor Risiko Kejadian Preeklampsia pada Ibu Melahirkan di RSIA Siti Fatimah Makassar. Skripsi. Universitas Hasanuddin. Makassar.

Betty F, dkk. 2009. Hubungan karakteristik ibu dengan kejadian preeklampsia di RSUI Yakssi Sragen. Akademi Kebidanan estu Utomo boyolali.

Kemenkes RI. 2008. Laporan nasional riset kesehatan dasar 2007. Kemenkes RI. Jakarta.

Hadjiko Y, Kadir S, Mursyidah A. 2014. Hubungan karakteristik ibu hamil dengan kejadian preeklampsia. Skripsi. Universitas Negeri Gorontalo. Gorontalo.

Hutabarat RA, Suparman E, Wagey F. 2016. Karakteristik pasien dengan preeklampsia di RSUP Prof. Dr. R. D. Kandou Manado. Jurnal e-Clinic (eCl). Vol 4(1); 31-35.

Ika KNR. 2009. Hubungan antara preeklamsia dengan bayi berat lahir rendah (BBLR). Jurnal penelitian Stikes Hang Tua Surabaya.

Kusika SY, Masni, Syafar M. 2014. Faktor risiko kejadian preeklampsia di Rumah Sakit Umum Anutapura Palu. (Tesis). Universitas Hasanuddin. Makassar. 
Kiondo P, Maina GW, Bimenya GS, Tumwesigye NA, and Wandabwa J. 2012. Risk factors for pre-eclampsia in mulago hospital, kampala, Uganda. Tropical Medicine and International Health. Vol 17(4); 480-487.

Nuryani, Magfirah AA, Citrakesumasari, Alharini S. 2013. Hubungan pola makan, sosial ekonomi, antenatal care dan karaktersitik ibu hamil dengan kasus preeklampsia di Kota Masakassar. Media gizi masyarakat Indonesia. Vol 2(2); 103-113.

Rahmadani A dkk. 2013. Faktor-faktor yang berhubungan dengan terjadinya preeklampsia / eklampsia.

Rozikhan. 2007. Faktor-Faktor Terjadinya Preeklampsia Berat. Tesis. Universitas Diponegoro. Semarang.

Senden IG. 2011. Severe early onset preeclampsia. Thesis the Erasmus Medical Center Rotterdam. Department of Obstetrics and Gynaecology, Division of Obstetrics and Prenatal Medicine. Netherland. 